\title{
PERMIT REQUIREMENTS FOR DEVELOPMENT OF ENERGY AND \\ OTHER SELECTED NATURAL RESOURCES FOR THE \\ STATE OF OHIO
}

PREPARED FOR

APPALACHIAN REGIONAL COMMISSION

AND THE

U.S. GEOLOGICAL SURVEY

BY BARRY LAWSON ASSOCIATES

This material is the result of tax-supported research and as such it is not subject to copyright. It may be freely reprinted with customary credit to the source. None of the findings, conclusions, or recommendations in the data are endorsed by the Appalachian Regional Commission, or the U.S. Geological Survey.

U.S. Geological Survey Open-File Report 81-1274 


\title{
ACKNOWLEDGEMENTS
}

The Ohio Permit Guide was prepared under the direction of the U.S. Geological Survey (USGS) in cooperation with the Appalachian Regional Commission and the State of Ohio. Funding support for this project was provided by the USGS Environmental Affairs Office (EAO) . Wilbert J. Ulman and James Frederick of the USGS Resource Planning and Analysis Office (RPAO) served respectively as Program Manager and Project Coordinator during the preparation of this guidebook. Both the RPAO and EAO are under the Office of Earth Sciences Applications. John Demchalk, Energy and Reclamation Advisor of the Appalachian Regional Commission, acted as Project Manager. Barry Lawson Associates, Inc. (BLA), of Boston, Massachusetts, was responsible for compiling all available information and producing the final document. Barry Lawson acted as Principal Investigator and Barbara Turoff as Project Coordinator during the preparation of this guidebook at BLA.

Request for information concerning this publication should be directed to the following locations:

State of Ohio

Department of Economic and

Community Development

P.O. Box 1001

Columbus, Ohio 43216
Appalachian Regional Commission 1666 Connecticut Avenue, N.W. Washington, D.C. 20235

or

\author{
U.S. Geological Survey \\ Environmental Affairs office \\ 760 National Center \\ Reston, Virginia 22092
}

\section{PUBLICATION AVAILABILITY}

This Ohio Permit Guide is available as an Open-File Report \#81-1274 from:

\author{
U.S. Geological Survey \\ Open-File Services Section \\ Branch of Distribution \\ Box 25425 \\ Denver Federal Center \\ Denver, Colorado 80225
}


STATE PERMIT REQUIREMENTS FOR DEVELOPMENT OF ENERGY AND OTHER SELECTED NATURAL RESOURCES

STATE PERMIT GUIDES WILL BE AVAILABLE BY JANUARY 1982 FROM, USGS OPEN-FILE SERVICES SECTION, BRANCH OF DISTRIBUTION, BOX 25425, DENVER, COLORADO 80225

State

Alabama

Alaska

Arizona

Arkansas

California

Colorado

Florida

Georgia

Idaho

Illinois

Indiana

Kansas

Kentucky

Louisiana

Maryland

Michigan

Minnesota

Missouri

Mississippi

Montana
Open File

$81-1248$

81-1249

$81-1250$

81-1251

81-1252

$81-1253$

$81-1254$

$81-1255$

$81-1256$

$81-1257$

$81-1258$

81-1259

$81-1260$

$81-1261$

$81-1262$

$81-1263$

$81-1264$

$81-1265$

$81-1266$

81-1267
State

Nebraska

New Mexico

New York

Nevada

North Carolina

North Dakota

Ohio

$81 \div 1274$

Oklahoma

$81-1275$

Oregon

$81-1276$

Pennsylvania $\quad 81-1277$

South Carolina 81-1278

South Dakota 81-1279

Tennessee

$81-1280$

Texas

$81-1281$

Utah

$81-1282$

Virginia

$81-1283$

Washington

$81-1284$

West Virginia

81-1285

Wisconsin

$81-1286$

Wyoming

81-1287

Publication dates for all permit guides are from August to December 1981 
CONTENTS

Page

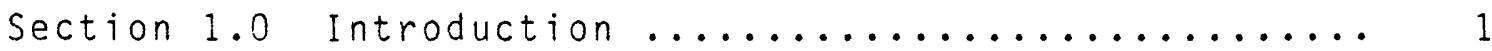

Section 2.0 State Policy and Procedures For

Consolidated Permit Program

Chapter 2.1 State Clearinghouse ........... 4

2.2 Ohio Environmental

Protection Agency............ 5

Section 3.0 Resource Extraction

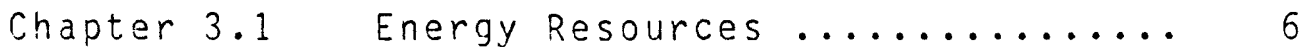

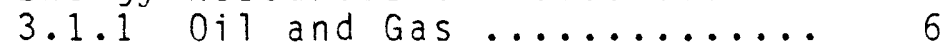

3.1 .2 Strip Mining ............ 8

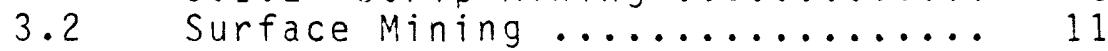

3.3 Removal of Minerals

from Lake Erie ............ 13

Section 4.0 Land Use Regulation

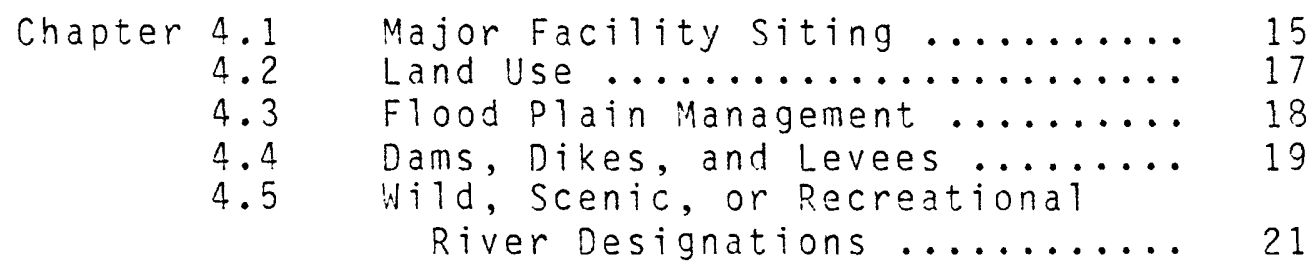

Section 5.0 Environmental Quality Management

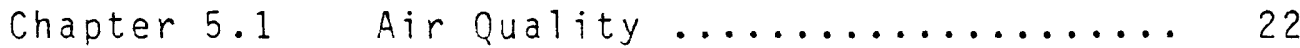

5.2 Water Quality Standards and



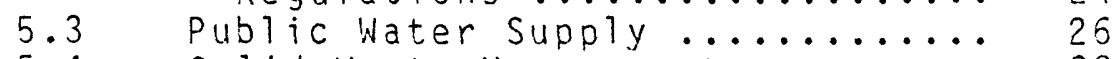

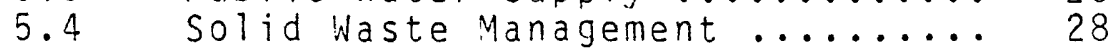

5.5 Hazardous Waste Management ..... 30

5.6 Noise Regulations ............. 32 
Section 6.0 Social/Ecological Preservation

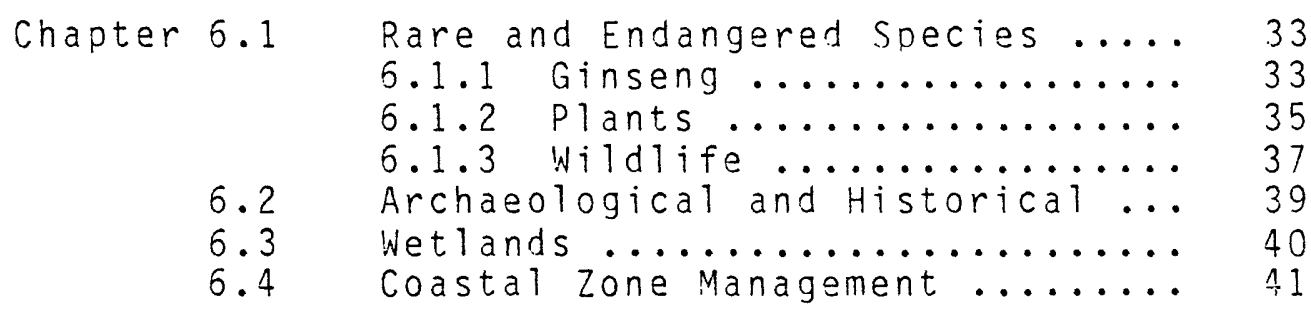

Section 7.0 Local Regulatory Policy

Chapter 7.1 Local Government Land IJse and Natural Resource Control

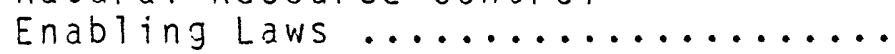


SECTION 1.0

INTRODUCTION 
This state permit guide for ohio is one in a series of guidebooks prepared to explain state regulations governing the environmental consequences of the development of energy and other natural resources on state and private land. (This guidebook does not address federal permits required on Federal 1 ands within the state.) It is designed to provide individuals in both government and the private sector with a concise compilation of State regulations and policies dealing primarily with permitting processes concerning natural resource management and development.

The increasing number of state policies and regulations concerning natural resources, especially energy resources, makes it difficult to gain an accurate yet workable understanding of State procedures without considerable research and technical assistance. The permit guide therefore serves as a reference document to those seeking state environmental and energy resource permit information. It is intended to show clearly what is required by regulatory and permit-issuing state agencies relative to a number of resource- and energy-related areas.

All the information in this permit guide was obtained through personal interviews with representatives of the state agencies in ohio responsible for the management of a particular resource area. Additional information was obtained directly from the appropriate state laws and regulations. It should be noted that the research was done during the spring of 1981 and that regulations are subject to change.

Most of the state agencies responsible for issuing permits require that applications be submitted on standard forms they provide. Such forms are usually numbered and named by the agency. If no form number is identified in the text, the application form should be requested by name.

The permit guide does not include a legal analysis or interpretation of statutes or regulations, nor is it intended to serve legal purposes. It provides a general summary of environmental and energy resource permit processes within a number of state agencies, and supplies information on selected state and local 
policies and procedures, land use regulations, and environmental management. For each subject, the permit guide provides the following information:

\author{
Name of Permit \\ Authorizing Statute \\ Title of Regulation \\ Summary of Permit Process \\ Administering Agency
}

Corresponding to the growth of Federal, State, and local regulatory powers, the number of formal approvals necessary to initiate a specific development activity has increased substantially. Although each chapter of this guide outlines the major State approvals required for a particular development activity, they do not provide a comprehensive list of the broad range of permits, licenses, and approvals which could potentially be required for an activity, nor do they cross reference other potentially relevant chapters of the guide.

To demonstrate the complexity of this situation, the introduction to the Strip Mining chapter (Chapter 3.1.2) of this guide includes a list of all state approvals which could potentially be required to initiate mining activities depending on the nature, location, and magnitude of the proposed activities. Such detailed cross referencing and analysis for all chapters is beyond the purpose and scope of this document. Therefore, initial direct contact with the appropriate state agency(ies) is recommended for anyone contemplating a project requiring a permit or other state agency approval. 
The following agencies were surveyed and have verified the content of the elements of their particular resource areas:

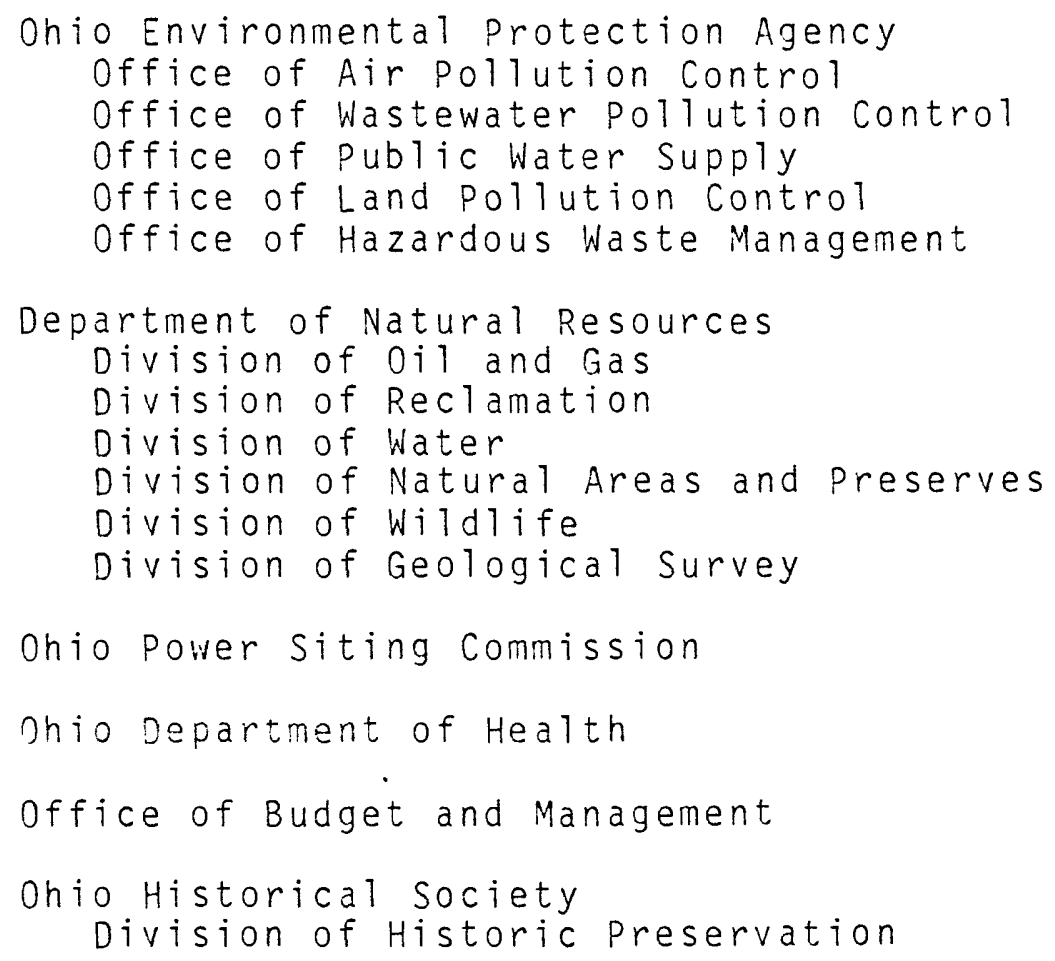


SECTION 2.0

STATE POLICY AND PROCEDURES FOR

CONSOLIDATED PERMIT PROGRAM

$3 a$ 


\section{STATE CLEARINGHOUSE}

INTRODUCTION: The Ohio State Clearinghouse operates within the Office of Budget and Management to review applications for Federal grants and environmental impact statements. The Clearinghouse, authorized by an Executive order from the Governor, was established to implement sections of the Federal Intergovernmental Cooperation Act of 1966 and the Demonstration Cities and Metropolitan Development Act of 1968. Review requirements are outlined in the Federal Office of Management and Budget's revised Circular A-95.

The State clearinghouse, working with areawide clearinghouses, determines whether a proposed grant or project will coordinate with state programs and policies. The clearinghouse process is advisory only and is intended to provide information on proposed Federal actions, avoid duplication of effort, and promote interagency coordination.

Applicants for Federal programs requiring A-95 review must contact both the State Clearinghouse and the appropriate areawide clearinghouses. The period of review varies from 30 to 50 days, depending on the type of project or grant involved. The applicant should reply to all comments, and the clearinghouse can provide opportunities for discussion between the applicant and the relevant agency(ies). The Federal funding agency also has the responsibility to respond to all negative or conditional comments and to notify the clearinghouse of its funding decisions.

ADMINISTERING AGENCY: $\quad$ Office of Budget and Management State Office Tower, 39 th Floor 30 East Broad Street Columbus, OH 43215

(614) $466-7461$ 


\section{OHIO ENVIRONMENTAL PROTECTION AGENCY}

INTRODUCTION: The State of Ohio does not have a State equivalent of the National Environmental Policy Act. However, the State's Environmental Protection Agency Act created the Ohio Environmental Protection Agency (Ohio EPA). This Agency has regulatory authority over air, drinking water, solid and hazardous waste, and water quality programs at the state level.

Although Ohio does not have a one-stop permit agency, the ohio EPA does utilize a uniform permit process for several of its programs. The application process for a permit to install a new source of pollution is the same for air, water and solid waste programs. The application process also provides for any combined permits that are necessary and involves the same procedural rules and fee systems for all programs. Section 5.0 of this guide, Environmental Quality Management, contains additional information concerning these areas.

ADMINISTERING AGENCY: Ohio Environmental Protection Agency 361 East Broad Street

P.0. Box 1049

Columbus, $\mathrm{OH} 43216$

(614) 466-8565 
SECTION 3.0

RESOURCE EXTRACTION

$5 a$ 


\section{CHAPTER 3.1}

\section{ENERGY RESOURCES}

\section{1 .1 OIL AND GAS}

INTRODUCTION: The Ohio Department of Natural Resources, Division of $0 i l$ and Gas has the authority to regulate the development, production, and use of oil and gas resources. The Division issues permits for a variety of oil and gas activities, including drilling, reopening, plugging, deepening, and converting wells.

A. NAMES OF PERMITS:

1. Well Drilling and Operation Permit

2. Well Plugging Permit

B. AUTHORIZING STATUTE: Ohio Revised Code, 0il and Gas Law, Sections 1509.01 through 1509.99

C. TITLE OF REgULATION: Rules of the Division of 0 il and Gas, Sections 1501:9-1-01 through 1501:9-13-17

\section{SUMMARY OF PERMIT PROCESS:}

1. Applicability: The drilling of a new well, drilling an existing well deeper, reopening a well, converting a well to any use other than its original purpose, or plugging back a well to a source of supply different from the existing pool.

2. General Requirements: A well drilling permit is required for any new drilling, or to reopen or convert an existing well. A permit is also necessary to plug and abandon a well that has been producing.

3. Submission Requirements: An application should be filed with the Division of $0 i l$ and Gas on designated forms. They must contain the following information: names, addresses, and signatures of owners and/or agents; location of tract or drilling unit; designation of well by name and number; geological formation to be tested and proposed total depth of the well; type of drilling equipment; corporate surety and bond identification; plan for disposal of wastes; and in cases of liquid injection, the geological formation and composition of the liquid. Applications must be accompanied by a map showing well location. It must be shown that well spacing requirements have been be adhered to. If an application concerns a well located in a coal bearing township, the Chief of the Division of Mines will be given copies of the application by the Chief of the Division of 0il and Gas. 
4. Procedure for Obtaining a Permit: Prior to being issued a permit, the owner must execute and file a surety bond conditioned on compliance with restoration and plugging requirements and with permit provisions. In lieu of the bond, cash or certificates of deposit will be accepted. The Chief of the Division of $0 i 1$ and Gas has 15 working days from the receipt of an application either to issue a permit or to notify the applicant of objections.

5. Operation Requirements: Within 30 days after completion of the well, an accurate log must be filed with the Division of $0 i l$ and Gas including information on the purpose of the well; descriptions of geological formations encountered; lengths of casing and tubing; identification as a dry, gas, oil, combination oil and gas, brine, or artificial brine well; and elevation of the well. A copy of the electric, radioactivity, or other geophysical $10 \mathrm{~g}$, if run, must also be given to the Division of $0 i l$ and Gas. In addition, the owner of a producing well or a well capable of producing oil or gas, must file a yearly statement of production.

6. Fees: Well drilling and operation permit: $\$ 95$

Plug and abandon permit: $\$ 20$

7. Appeals: Anyone aggrieved by a decision by the Division of $0 i l$ and Gas may appeal to the $0 i l$ and Gas Board of Review. Decisions of the Board may also be appealed, within 30 days, to the Court of Common Pleas of Franklin County.

E. ADMINISTERING AGENCY: Division of $0 i 1$ and Gas

Department of Natural Resources

Fountain Square

Columbus, OH 43224

(614) $466-3990$ 


\subsubsection{STRIP MINING}

INTRODUCTION: The Ohio Department of Natural Resources, Division of Reclamation has the authority to regulate strip mining in order to protect the environment. The Program involves a permit process and the licensing of strip mine operators.

In addition to the strip mining operator's license and strip mine permit, depending on the location, nature, and magnitude of the proposed activities, prospective mine operators may also be required to obtain the following permits, licenses, and approvals:

- authorization to construct drainage controls from the Division of Reclamation,

- permits for open pit excavation or for disposal of mine refuse near public roads from the Department of Transportation, county commissioners, or township trustees, as applicable,

- certification from the Federal Mine Safety and Health Administration for underground mines,

- approval from county commissioners for drainage ditches,

- blaster's certification from the Division,

- local permits to construct in flood plains (See Chapter 4.3 of this guide),

- permits to construct dams, dikes, and levees (See Chapter 4.4 of this guide),

- NPDES permits and permits to install wastewater facilities (See Chapter 5.2 of this guide),

- Solid and hazardous waste disposal permits (See Chapters 5.4 and 5.5 of this guide),

- permits to construct in wetlands areas (See Chapter 6.3 of this guide), and

- compliance with local zoning ordinances (See Chapter 7.1 of this guide).

A. NAMES OF PERMITS:

1. Strip Mine Permit

2. Operator's License 
B. AUTHORIZING STATUTE: Ohio Revised Code, Strip Mining and Reclamation of Mined Land, Sections 1513.01 through 1513.99

C. TITLE OF REgULATION: Ohio Strip Mining Rules, Chapter 1501:13-3-01 through 1501:13-21-03

D. SUMMARY OF PERMIT PROCESS:

1. Applicability: The operation of strip mines.

2. General Requirements: Strip mine operators must be licensed, and strip mining operations require permits.

3. Submission Requirements: License applications must be on prescribed forms and furnish appropriate names and addresses, past license history, and a certificate of public liability insurance. Strip mine permit applications must also be on designated forms and include appropriate names and addresses, a description of land to be mined, test reports, and a complete plan for mining and reclamation which includes costs and maps.

4. Procedure for Obtaining a Permit and Operator's License: Application forms and fees are filed with the Division of Reclamation. The application is then sent to the appropriate district office for a review which will involve an on-site inspection.

The Division of Reclamation issues an order to grant or deny a license or permit within a prescribed period after receipt of the completed application, required fee, and bond. A permit is issued for 3 years and a license must be renewed annually.

5. Operation Requirements: Upon 30 days notice, progress reports may be required from the operator. The operator must file an annual report which must include the following information about the year's operation: amount of coal produced, number of acres affected and number of acres reclaimed, description of the area of land affected and the area of land reclaimed, and an estimate of the number of acres to be affected during the next year of operation. Reports must also include a progress map and appropriate bonds.

Operators must comply with regulations dealing with reclamation of the mined area as outlined in section 1513.16 of the Regulations.

All strip mining operations must be in compliance with all requirements to protect the environment, including requirements for: disposal of spoil and waste materials, drainage systems, auger mining, deep mine intrusions, and steep slope mining. 
6. Fees: License fee: $\$ 150$

Permit fee: $\$ 50$ per acre of land affected

7. Appeals: Appeals may be made to the Reclamation Board of Review for an order vacating or modifying the decision of the Division Chief.

E. ADMINISTERING AGENCY: Division of Reclamation Department of Natural Resources Fountain square

Col umbus, OH 43224

(614) $466-4850$ 
INTRODUCTION: The Ohio Department of Natural Resources, Division of Reclamation has the authority to regulate surface mining activities in order to protect the environment. The regulatory program involves a permit process for surface mining operations.

A. NAME OF PERMIT: Surface Mine Permit

B. AUTHORIZING STATUTE: Ohio Revised Code, Surface Mining and Reclamation of Mined Land, Sections 1514.01 through 1514.99

C. TITLE OF REgULATION: Ohio Surface Mine Rules, sections NRIM-I-O1 through NRIM-IV-O4

D. SUMMARY OF PERMIT PROCESS:

1. Applicability: The operation of surface mines.

2. General Requirements: A surface mining permit is required for all surface mining operations. Surface mining operations must comply with all requirements to maintain the quality of the environment.

3. Submission Requirements: The application must be on forms prescribed by the Division of Reclamation and contain the following information: appropriate names and addresses, a description of minerals sought for extraction, a detailed description of land area sought for the mining activity, test boring results, a plan for mining and reclamation, a map prepared by a registered engineer or surveyor, a certificate of public liability insurance, and proof of filing of the performance bond.

4. Procedure for obtaining a Permit: Application forms and fees are filed with the Division of Reclamation. Once application materials are deemed to be complete, the appropriate district office reviews the application, including an on-site inspection. The Chief of the Division of Reclamation may then approve an application and issue an order granting a permit.

5. Operation Requirements: Within 30 days of annual permit renewal, the operator must submit an annual report, or final report, if appropriate, to the Division of Reclamation on prescribed forms, including such information as: amounts and types of minerals produced, number of acres affected during the year's operations, and acreage estimated to be affected during the next year. Reports must also include a progress map and appropriate filing fees and bonds. 
The mine operator must also comply with regulations concerning use of explosives (Section NRim-III-04) and regulations concerning the reclamation of the land, including protection of underground water supplies, final slopes, highwalls, resoiling, and revegetation (section NRim-III-05-10).

6. Fees: Permit application fee: $\$ 150$

Acreage fee: $\$ 30$ per acre of land to be affected within the first year of operation, but not to exceed $\$ 1,000$ per year.

7. Appeals: Appeals may be made to the Reclamation Board of Review for an order vacating or modifying the decision of the Division Chief.

E. ADMINISTERING AGENCY: Division of Reclamation

Department of Natural Resources

Fountain Square

Columbus, OH 43224

(614) $466-4850$ 


\section{REMOVAL OF MINERALS FROM LAKE ERIE}

INTRODUCTION: The Ohio Department of Natural Resources, Division of Geological Survey has the authority to regulate the removal of minerals and mining operations under the bed of Lake Erie. The program involves a permit process and leases for mining operations, however, no regulations have been promulgated.

\section{A. NAME OF PERMIT: Permit for Removal of Minerals from Lake Erie}

B. AUTHORIZING STATUTE: Ohio Revised Code, Removal Permits for Minerals, Section 1505.07

C. TITLE OF REGULATION: No regulations have been adopted. Regulatory requirements and permitting processes are included in the Act.

\section{SUMMARY OF PERMIT PROCESS:}

1. Applicability: The removal of sand, gravel, stone, gas, oil, and other minerals from under the bed of Lake Erie.

2. General Requirements: A permit and lease for a specified term are required for all mining operations.

3. Submission Requirements: Application materials must include information on the applicant's background, including past experience and assets and information on vessels involved in dredging operations, including their capacity and any identification marks.

4. Procedure for Obtaining a Permit and Lease: The Director of the Department of Natural Resources, with the approval of the Director of the Ohio Environmental Protection Agency, Attorney General, and the Governor, may issue permits and make leases to applicants, on a royalty or rental basis. Applications are evaluated case by case.

5. Operation Requirements: Field investigations by Department of Natural Resources staff may be conducted to ensure compliance with permit requirements. Permits are issued for 1 to 10 years, and leases for a term of 3 years or until the economic extraction of the mineral has been completed. All operations must be maintained within the designated boundaries. 
6. Fees: There is no fee for a lease. Fees for removal of minerals are: for rental, a flat annual fee; for royalty, a flat fee rate such as $\$ .20$ per cubic yard for sand or gravel, or a percentage of the commodity exchange price for minerals such as salt.

7. Appeals: There is no formal appeals process.

E. ADMINISTERING AGENCY: Division of Geological Survey Department of Natural Resources Fountain Square, Building 3 Columbus, $\mathrm{OH} \quad 43224$ (614) $466-5344$ 
SECTION 4.0

LAND USE REGULATION

$14 a$ 


\section{MAJOR FACILITY SITING}

INTRODUCTION: The Ohio Power Siting Law creates a Power siting Commission (Ohio PSC) which is responsible for approving the location of major electric generating, electric transmission, and gas transmission facilities.

A. NAME OF APPROVAL: Certificate of Environmental Compatibility and Public Need

B. AUTHORIZING STATUTE: Ohio Revised Code, Power Siting Law, Chapter 4906

C. TITLE OF REgULATION: Ohio Power Siting Commission Rules and Regulations, Ohio Administrative Code, Sections 4906-1-01 through 4906-15-12

D. SUMMARY OF CERTIFICATION PROCESS:

1. Applicability: The location, construction, operation, and maintenance of major utility facilities defined as electric generating plants of $50 \mathrm{MW}$ or greater, electric transmission lines of $125 \mathrm{KV}$ or greater, and gas transmission 1 ines of 125 PSI or greater.

2. General Requirements: A certificate of environmental compatibility and public need is required from the ohio PSC for the location, construction, operation, and maintenance of major utility facilities.

3. Submission Requirements: A utility application must be submitted to Ohio PSC according to ohio PSC rules for all major utility facilities. Utilities seeking approval for a power plant must file a letter of intent 1 year before submission of an application. Applications must demonstrate: 1) the need for the facility; 2) the nature of the probable environmental impacts; 3) whether the facility will have a minimal environmental impact; 4) in the case of an electric transmission line, that the facility is consistent with regional plans to expand the electric power grid; 5) that the facility will comply with all air and water pollution control and solid waste disposal laws; and 6) that the facility will serve the public interest, convenience, and necessity. 
4. Procedure for obtaining a Certificate: Utilities may request a pre-application conference with the ohio PSC. Once the application is received, the Ohio PSC has 60 days to determine whether it contains all of the information required by Ohio PSC rules and regulations. When the application is certified as complete, the utility provides copies of the application to appropriate state agencies, municipalities, counties, and regional planning agencies. A public hearing is scheduled for which a public notice is required. An administrative law judge ( $A L J$ ) conducts the hearing and associated proceedings. After the hearing, the ALJ prepares findings and makes a recommendation to the ohio PSC. The Ohio PSC approves or denies the certificate on the basis of the record. The ohio PSC evaluates each case based upon the 6 criteria listed under Submission Requirements.

5. Operation Requirements: The Ohio PSC has statewide preemptive jurisdiction for issuing and enforcing certificates as described. Individual State agencies, however, retain responsibility for their mandated functions as prescribed by law.

6. Fees: Application fees are required, as prescribed in Section 4096-5-11 of the regulations, and are computed based upon type of facility and its capacity.

7. Appeals: All decisions of the Ohio PSC may be appealed back to the Ohio PSC and then directly to the ohio supreme court.

E. ADMINISTERING AGENCY: Ohio Power Siting Commission

361 East Broad Street

Columbus, $\mathrm{OH} 43215$

(614) 466-6422 


\section{CHAPTER 4.2}

LAND USE

INTRODUCTION: The State of Ohio has no regulatory authority with respect to land use or critical areas. The Ohio Department of Natural Resources does provide computerized county and regional physical resource data through the Ohio Capability Analysis Program (OCAP). Information on soils, geology, and land use are some of the data available through the OCAP. This information is used by local officials to assist them in making land use decisions.

In addition, the Ohio Department of Natural Resources has a Critical Areas Program that provides technical assistance upon request to local governments interested in developing management plans to protect or conserve critical resource areas. The Department also conducts a semiannual short course on land use planning for county, township, and municipal officials.

Department of Natural Resources

Fountain Square

Columbus, OH 43224

(614) $466-6294$ 


\section{CHAPTER 4.3}

\section{FLOOD PLAIN MANAGEMENT}

INTRODUCTION: The Ohio Department of Natural Resources (DNR) provides technical and planning assistance to Ohio's residents and local governments on flooding and flood plain management. The DNR is the State coordinating agency for the National Flood Insurance Program administered by the Federal Emergency Management Agency (FEMA). Flood-prone communities may elect to participate in this program, which makes available inexpensive flood insurance. In return, communities must meet Federal flood plain management criteria. The DNR functions primarily in an advisory capacity and its regulatory authority is 1 imited to reviewing public facilities.

Local governments and State agencies must notify and consult with the DNR, Division of Water prior to construction of public facilities located in flood-prone areas. (Ohio Revised Code, Section 1521.14)

ADMINISTERING AGENCY:

Division of Water

Department of Natural Resources

Fountain Square

Columbus, $\mathrm{OH} 43224$

(614) $466-6020$ 
DAMS, DIKES, AND LEVEES

INTRODUCTION: The Ohio Department of Natural Resources (DNR), Division of water has the authority to regulate the construction of new dams, dikes, and levees, and to coordinate inspections of such structures. The purpose of the law is to assure the proper design and construction of a dam, dike, or levee so that life, health, and property will not be endangered. The basic control involves a construction permit process.

A. NAME OF PERMIT: Dam Construction Permit

B. AUTHORIZING STATUTE: Sections 1521.06, 1521.061, 1521.062, and 1521.07, Ohio Revised Code, Dam Permit and Inspection Statutes

C. TITLE OF REgULATION: Dam Permit and Inspection Program

D. SUMMARY OF REGULATION:

1. Applicability: Construction or modification of all dikes, levees, and dams higher than 10 feet with certain exemptions, such as U.S. Army corps of Engineers dams, and dams designed by local soil conservation districts.

2. General Requirements: A permit is required for the construction of applicable dams, dikes, and levees.

3. Submission Requirements: In order to obtain a permit, applicants must initially submit preliminary construction plans to the DNR and a final design report. Then designated application forms must be submitted, including final design plans and specifications prepared by a registered professional engineer.

4. Procedure for obtaining a Permit: The DNR will either issue or deny a permit for construction. When issued, the permit is valid for 2 years. The completed dam must be certified by a registered professional engineer prior to its use.

5. Operation Requirements: A pre-final inspection upon completion of construction is required, followed by a final inspection 1 year later. If the dam passes final inspection, bond is released. No regulatory penalties exist other than the holding of the bond. 
6. Fees: Application fee: $\$ 100$ plus a surety bond for at least $1 / 2$ the estimated cost of construction.

7. Special Notes: Dams are inspected to protect life health, and property. The State's inspection program requires all dams over 10 feet to be inspected once per 5 years. They are reviewed on a priority basis by a team of 8 engineers working for the Division of Water. The Division can order changes to protect 1 ife, health, and property. The State can improve the hazard if the owner does not, and the State then places the actual cost of improvement construction as a lien on the property.

There are 6500 dams covered under the Division's inpsection program, and most of these dams are related to private or public recreation, although several do involve coal mining or power plant operations.

E. ADMINISTERING AGENCY: Division of water

Department of Natural Resources

Fountain Square

Columbus, OH 43224

(614) $466-2646$ 
WILD, SCENIC, OR RECREATIONAL RIVER DESIGNATIONS

INTRODUCTION: This program allows the Ohio Department of Natural Resources to create, supervise, operate, protect, and maintain wild, scenic, and recreational river areas.

A. AUTHORIZING STATUTE: Ohio Revised Code, Section 1501.16

B. TITLE OF REgULATION: Creation of wild, Scenic, or Recreational River Areas, ORC 1501.16

C. SUMMARY OF REGULATION: The Ohio Department of Natural Resources (DNR) may create and manage wild, scenic, or recreational river areas on a part or parts of any water course of the state. Areas proposed for wild, scenic, or recreational river designations must possess water conservation, scenic, fish, wildife, hiscorlc, or outdoor recreation values which meet the river classification criteria. The Director of the DNR proposes a designation, publishes a notice of intent, and waits 30 days before making the designation. A wild, scenic, or recreational river area designation does not restrict the use of land by the owner.

D. ADMINISTERING AGENCY: Division of Natural Areas and Preserves

Department of Natural Resources

Fountain Square, Building F-1

Columbus, OH 43224

(614) $466-7803$ 
SECTION 5.0

ENVIRONMENTAL QUALITY MANAGEMENT

$21 a$ 
INTRODUCTION: Chapter 3704 of the Ohio Revised Code gives the Director of the Ohio Environmental Protection Agency (Ohio EPA) the authority to administer the State's air quality program. The regulations involve 2 basic control measures, a permit to install and a permit to operate new or existing sources of air pollution.

\section{A. NAMES OF PERMITS:}

1. Permit to Install

2. Permit to Operate

B. AUTHORIZING STATUTE: Chapter 3704 , Ohio Revised Code

C. TITLE OF REGULATION: Section 3745-31, Ohio Administrative Code: Permit to Install; Section 3745-35, Ohio Administrative Code: Permit to Operate

D. SUMMARY OF PERMIT PROCESS:

1. Applicability: Installation of new sources or modification of existing sources, and the operation or use of any air contaminant source.

2. General Requirements: A permit to install and a permit to operate from the Ohio EPA are required for new or modified sources of air contaminants.

3. Submission Requirements: To obtain a permit to install for a new or existing source, applicants must file a technical application to the appropriate field office for review and recommendation. Applications for permits to operate must be on forms prescribed by Ohio EPA, submitted to the appropriate field office, and must contain all information the agency deems necessary to determine whether the air contaminant source is operating and will be operating in accordance with all applicable rules of the Ohio EPA, including, but not limited to: location of source; description of equipment and processes involved; the nature, source, and quantity of uncontrolled and controlled emissions; the type, size, and efficiency of control facilities; and the impact of the emissions from such source upon existing air quality. 
4. Procedure for Obtaining a Permit: The Director of the Ohio EPA must follow the procedural rules as detailed in OAC3745-47 for issuing, modifying, revoking, or denying either the permit to install or the permit to operate. Within 180 days after a completed application is filed, the Director issues a proposed or final order, either granting or denying the permit. The procedural rules require the Ohio EPA to give public notice of proposed decisions, meetings, and hearings. Within 30 days of the notice of a proposed decision, anyone may petition for a public hearing.

5. Operation Requirements: The Ohio EPA has been delegated New Source Performance Standard (NSPS) and Prevention of Significant Deterioration (PSD) authority from the U.S. Environmental Protection Agency. The new or modified source of air pollution must comply with new source performance standards, prevention of significant deterioration criteria, offset policies, and interstate pollution abatement requirements, as applicable. The Director may require installation of monitoring and recording equipment. Permits to operate generally are valid for 3 years, though they may be allowed for shorter periods of time.

6. Fees: Fees range from $\$ 50$ to $\$ 325$ as listed in Rule 3745-45-04, Ohio Administrative Code, depending upon type and capacity of facility.

7. Appeals: Anyone aggrieved by a decision may appeal to the Environmental Board of Review within 30 days of the notice of the decision.

8. Special Notes: The Director may place an application for an operating permit on registration status rather than actually issuing a permit if certain minimal criteria pertaining to the amount of emissions are met. The owner or operator of such an air contaminant source must demonstrate that the source is in compliance with applicable air pollution control laws and that it meets certain operating conditions.

E. ADMINISTERING AGENCY: Office of Air Pollution Control

Ohio EPA

361 East Broad Street

P.0. Box 1049

Columbus, OH 43216

(614) 466-6116 


\section{WATER QUALITY STANDARDS AND REGULATIONS}

INTRODUCTION: The U.S. Environmental Protection Agency has granted the Ohio Environmental Protection Agency (Ohio EPA) the authority to administer National Pollutant Discharge Elimination System permits (NPDES) and to set water quality standards. Ohio's water quality legislation works toward all state waters becoming suitable for fishing and swimming.

\section{A. NAMES OF PERMITS:}

1. NPDES Permit

2. Permit to Install

B. AUTHORIZING STATUTE: Ohio Revised Code 6111, water Quality Standards

C. TITLE OF REGULATION: Ohio Administrative Code, Section 3745-1: Water Quality Standards; Section 2745-31: Permit to Instal1; Section 3745-33: Ohio NPDES Permits; Section 3745-45: Permit Fees

\section{SUMMARY OF PERMIT PROCESS:}

1. Applicability: All new, modified, or existing point sources of water pollution, point sources being discernable conveyances from which water pollutants are or may be discharged.

2. General Requirements: NPDES permits are required for all point source discharges. New or modified industrial point sources require a permit to install and an NPDES permit. New or modified municipal point sources, existing industrial point sources, and all existing municipal sewage treatment facilities must have an NPDES permit.

3. Submission Requirements: Applicants must file the appropriate technical applications with the Ohio EPA for a permit to install, and for the NPDES permit, including detailed plans and specifications of the proposed treatment facility. 
4. Procedure for Obtaining a Permit: The Director of the Ohio EPA must follow the procedural rules as detailed in OAC3745-47, for issuing, modifying, revoking, or denying the permit to install. Within 180 days after a completed application is filed, the Director will issue a proposed or a final order granting or denying the permit. The procedural rules require the Ohio EPA to give public notice of proposed decisions, meetings, and hearings. Within 30 days of the notice of a proposed decision, anyone may petition for a public hearing. Permits may be issued for up to 5 years.

5. Operation Requirements: NPDES permittees must submit monthly reports to the Ohio EPA and report any violations. The permit states the maximum level of pollutants which may be discharged in order to be in compliance with water quality standards, technology-based effluent limitations, and prohibition of significant degradation. These requirements must be adhered to.

6. Fees: Fees are determined under Rule 3745-45-03 of the Ohio Administrative Code for water discharge permit fees and Rule 3745-45-02 for permits to install.

7. Appeals: Anyone aggrieved by a decision may appeal to the Environmental Board of Review within 30 days of the notice of the decision.

E. ADMINISTERING AGENCY: Office of Wastewater Pollution Control

Oh io EPA

361 East Broad Street

P.0. Box 1049

Columbus, OH 43215

(614) 466-7427 
PUBLIC WATER SUPPLY

INTRODUCTION: The Ohio Environmental protection Agency (Ohio EPA) has broad regulatory authority over the construction, operation, and maintenance of all public water supplies, both groundwater arid surface water, whether publicly or privately owned. The Ohio EPA has primary enforcement responsibility for administering the U.S. Environmental Protection Agency (U.S. EPA) regulations under the Federal Safe Drinking water Act of 1974 .

A. NAME OF APPROVAL: Plan Approval for Public water Supply Systems

B. AUTHORIZING STATUTE: Ohio Revised Code 6109 - Public water Supply Law; Chapter 119

C. TITLE OF REGULATION: Public water systems, Ohio Administrative Code, Sections 3745-81, 82, 83, 85, 89, 91 , 92,95 , and 99

D. SUMMARY OF PLAN APPROVAL PROCESS:

1. Applicability: All public water supplies and water treatment works (both groundwater and surface water, whether publicly or investor-owned) which provide piped water for human consumption with at least 15 service connections or which regularly serve at least 25 persons at least 60 days per year.

2. General Requirements: Plan review and approval by the Ohio EPA is required for new or modified water supplies or water treatment works.

3. Submission Requirements: Plans must comply with Rule 3745.91 and include a site map, describe existing water supply facilities, show all dimensions of all structures, and show the locations of sewer lines and other potential sources of contamination. Detailed specifications are required on al1 hardware, including wells, valves, pumps, pipes, treatment devices, laboratory equipment, etc.

4. Procedure for Obtaining Plan Approval: Once application materials are deemed complete, the Director of the Ohio EPA will either approve or disapprove the plans, based on their compliance with the Federal Safe orinking water Act and general construction standards. 
5. Operation Requirements: Regular monitoring of public water systems is required and results must be reported to the Ohio EPA. Public notification is required for failure to comply with any requirement of State Primary Drinking Water rules. Monthly operation reports are required.

The Ohio EPA requires a certified operator for any water supply works servicing 250 or more persons. The Ohio EPA sets prerequisites and provides for the examination and certification of water supply works operators. The Ohio EPA can order changes if the existing water supply is in danger of contamination because of unsatisfactory location or improper construction, maintenance, or operation.

6. Fees: There are no fees, though an escrow deposit is required for some facilities.

7. Appeals: Anyone aggrieved by a decision may appeal to the Environmental Board of Review within 30 days of the notice of the decision.

E. ADMINISTERING AGENCY: Office of Public water Supply

Oh io EPA

361 East Broad Street

P.0. Box 1049

Columbus, $\mathrm{OH} 43216$

(614) 466-8307 
INTRODUCTION: Under the Resource Conservation and Recovery Act of 1976 (RCRA), the U.S. Environmental Protection Agency issued interim guidelines to assist states in developing comprehensive solid waste management programs. Continual planning and implementation are required at the state level to maintain Federal funding eligibility under Subtitle $D$. The Ohio Revised Code, Chapter 3734 sets forth Ohio's policies and regulations on solid waste management. The basic control measures consist of a permit to install and a 1 icense to operate.

A. NAMES OF PERMITS:

1. Permit to Install

2. License to operate

B. AUTHORIZING STATUTE: Chapter 3734, Ohio Revised Code

C. TITLE OF REGULATION: Section 3745-31, Ohio Administrative Code: Permit to Install; Section 3745-35, Ohio Administrative Code: Permit to operate

D. SUMMARY OF PERMIT PROCESS:

1. Applicability: Installation of a new site or modification of existing site. The operation of any solid waste management facility.

2. General Requirements: Plans for all new or substantially modified sites and facilities must be approved by the onio Environmental Protection Agency (Ohio EPA). A permit to install is also required by the Ohio EPA and a 1 icense to operate is required by the local health department (or the Ohio EPA if it has assumed program responsibility).

3. Submission Requirements: For a permit to install, the applicant must file application materials to the field office for review and recommendation.

A permit to operate is issued annually by the local health department, or by the Ohio EPA directly in those counties which are not approved to run the solid waste program. New or modified sites must have a site evaluation by an Onio EPA engineer and geologist. Applicants must submit detailed plans for the proposed facility to the onio EPA. Applications must also include written acknowledgement that detailed plans have been filed with the local zoning authority. 
4. Procedure for Obtaining a Permit and License: The Director of the Ohio EPA must follow the procedural rules as detailed in OAC-3745-47, for issuing, modifying, revoking, or denying the permit to install. Within 180 days after a completed application is filed, the Director issues a proposed or final order either granting or denying the permit. The procedural rules require the ohio EPA to give public notice of proposed decisions, meetings, and hearings. Withing 30 days of the notice of the proposed decision, anyone may petition for a public hearing.

5. Operation Requirements: Solid wastes may be disposed of by sanitary landfill, incineration, composting, or other approved methods, but not by open dumping or burning. In order to ensure proper operation with no resultant air or water pollution, measures for cover, compaction, adequate operating equipment, leachate control, erosion control, and control of blowing litter, noise, dust, and odor are specified in the regulations. Operators must follow specific plans for closure and must maintain monitoring wells on a landfill for 3 years following closure.

6. Fees: Fees are listed in Rule 3745-45-02, Ohio Administrative code. The annual operating permit fee is, at maximum, $\$ 500$.

7. Appeals: Anyone aggrieved by a decision may appeal to the Environmental Board of Review within 30 days of the notice of the decision.

E. ADMINISTERING AGENCY: Office of Land Pollution Control

Ohio EPA

361 East Broad Street

P.0. Box 1049

Columbus, OH 43216

(614) $466-8934$ 


\section{CHAPTER 5.5}

\section{HAZARDOUS WASTE MANAGEMENT}

INTRODUCTION: The State of Ohio presently has a cooperative agreement with the U.S. Environmental Protection Agency for planning hazardous waste management. The Ohio Environmental Protection Agency (Ohio EPA) has developed hazardous waste management regulations pertaining to the safe disposal, transportation, and storage of hazardous waste as authorized by the state legislature. Regulations and standards for hazardous waste generators, transporters, and treatment, storage, and disposal facilities are and will be substantially equivalent to the U.S. Environmental Protection Agency's hazardous waste regulations.

A. NAME OF PERMIT: Permit to Install and operate

B. AUTHORIZING STATUTE: Chapter 3734, Ohio Revised Code

C. TITLE OF REgulation: Rules of the Ohio ePA, Hazardous Waste

D. SUMMARY OF REGULATION:

1. Applicability: Generators, transporters, and facilities for treatment, storage, and disposal are covered by the regulations. Only treatment, storage and disposal facilities are covered by permitting procedures. Transporters must register with the Public Utilities Commission of Ohio.

2. General Requirements: All operators of new and existing hazardous waste treatment, storage, and disposal facilities must obtain a permit to install and operate from the ohio EPA, subject to the approval of the Hazardous waste Facility Approval Board.

3. Submission Requirements: Prior to the submission of a permit application, the ohio EPA should be contacted regarding the siting of any new facility. Completed applications for a permit to install and operate should be submitted to the Ohio EPA. Completed applications are then reviewed and those which are recommended are forwarded to the Hazardous Waste Facility Approval Board for approval. This 5 -member board is composed of 3 state officials, a geologist, and a chemical engineer from a State university. 
4. Procedure for Obtaining a Permit: once a permit application with a preliminary recommendation of approval has been forwarded to the Board by the Ohio EPA, the Board arranges for a public hearing to be held within 90 days of its receipt of the application. The Board also arranges for an adjudication hearing at which the Board hears and decides all disputed issues between disagreeing parties during the review process. Currently, the applicant also must file appropriate permit application materials with Region V, U.S. Environmental Protection Agency. This procedure will be necessary until the state of Ohio receives authorization to enforce the Federal program.

5. Operation Requirements: After being issued a hazardous waste permit to install and operate, each facility is subject to the rules and supervision of the Director of the Ohio EPA during the period of operation and closure.

6. Fees: Permit application fee: $\$ 500$, which must be renewed annually. There are also disposal fees. For offsite facilities, a fee of 4 percent of disposal costs is to be collected by the disposal facility operator for the state. For on-site facilities, the annual fee is $\$ 1,000$ for each disposal facility up to 5 acres in size and $\$ 200$ for each additional acre or, $\$ 2,500$ for each deep well, or a combination of these amounts. The total annual fee will not exceed $\$ 5,000$.

7. Appeals: Any party adversely affected by an order of the Board may appeal the order and the decision of the Board to the Court of Appeals of Franklin County within 30 days of receipt of the notice from the Board.

8. Special Notes: Ohio's authorizing legislation calls for the development of regulations substantially equivalent to Federal regulations adopted under the Resource Conservation and Recovery Act. Nothing precludes the Director of the Ohio EPA from issuing regulations in the absence of Federal regulations.

E. ADMINISTERING AGENCY: Office of Hazardous Waste Management Ohio EPA

P.0. Box 1049

361 East Broad Street

Columbus, OH 43216

(614) 466-8565 
INTRODUCTION: The state of Ohio has no jurisdiction over noise except for in-plant problems and motor-vehicle mufflers. Most noise regulation is under local ordinance. The Ohio EPA acts as a technical consultant to the state Tax Commissioner regarding exemptions from a variety of state taxes for equipment installed by facilities to abate outdoor noise pollution, (Ohio Revised Code, 5709.20). The Ohio Department of Health is, however, in the process of setting up noise control programs in several of the State's major cities.

ADMINISTERING AGENCY:

Ohio Department of Health

246 North High Street

Columbus, OH 43215

(614) $466-2253$ 
SECTION 6.0

SOCIAL/ECOLOGICAL PRESERVATION

$32 a$ 


\section{CHAPTER 6.1 \\ RARE AND ENDANGERED SPECIES}

\section{1 .1 GINSENG}

INTRODUCTION: The Department of Natural Resources, Division of Natural Areas and Preserves has the authority to administer the Ohio Ginseng Management Program. This program was established under mandate of the U.S. Fish and Wildlife Service to carry out the Service's responsibility under the convention on International Trade in Endangered Species of Wild Fauna and Flora. The purpose of the program is to help protect American ginseng, a species of ginseng that may be threatened with extinction if trade is not subject to regulation. The basic control involves a permit process.

\section{A. NAMES OF PERMITS:}

1. Ohio Ginseng Dealer's Permit

2. Ohio Ginseng Grower's Registration Permit

B. AUTHORIZING STATUTE: Executive Order (Governor James A. Rhodes), dated August 1979

C. TITLE OF REgULATION: Ohio Ginseng Management Program

D. SUMMARY OF PERMIT PROCESS:

1. Applicability: The collection, buying, growing of, or dealing in ginseng.

2. General Requirements: Ginseng dealers must apply for a State dealer's permit annually. Ginseng growers must obtain a State registration permit.

3. Submission Requirements: A simple application form, including the dealer's or grower's name, address, signature, and past experience must be completed and submitted to the Division in order to obtain a dealer's permit or to register.

4. Procedure for obtaining a Permit: Growers and dealers must submit application materials to the Division for approval. The purpose of the registration and permit process is to monitor the amount of ginseng harvested and exported.

5. Permittee Requirements: Dealers must submit an annual report detailing: 1) total poundage of ginseng exported from Ohio; 2) number of export certification forms issued;

3 ) total value of ginseng exported from Ohio; 4) names and addresses of out-of-state dealers and/or exporters to whom ginseng was sold and poundage; and 5) poundage of ginseng purchased or harvested from each ohio county. 
6. Fees: None

E. ADMINISTERING AGENCY: Division of Natural Areas and Preserves

Department of Natural Resources

Fountain Square

Columbus, $\mathrm{OH} 43224$

(614) $466-7803$ 


\section{$6.1 .2 \quad$ PLANTS}

INTRODUCTION: The Department of Natural Resources, Division of Natural Areas and Preserves has the authority to administer regulations dealing with endangered plant species. The Ohio Endangered Plant Law was enacted to protect endangered and threatened Ohio plants and to implement sections of the Federal Endangered Species Act of 1973, as amended. The basic control involves a permit process for collecting.

A. NAME OF PERMIT: Collecting Permit

B. AUTHORIZING STATUTE: Chapter 1518, Ohio Revised Code: Ohio Endangered Plant Law

C. TITLE OF REgULATION: Ohio Endangered plant Law, Administrative Rules, Section 1501.18-1-03.04

D. SUMMARY OF PERMIT PROCESS:

1. Applicability: Taking, transporting, or possessing wild endangered or threatened plant species.

2. General Requirements: A collecting permit is required for the taking, transporting, or possession of any natural species of wild plants listed as endangered or threatened, for botanical, educational, or scientific purposes, or for propagation in captivity to preserve a species.

3. Submission Requirements: An application for a permit must provide the following information: 1) a program or project description with a clear statement of study objectives; 2) justification of the study; 3 ) project location; 4) duration of the study; 5) species and number of specimens to be collected or involved in the study; and 6) assurance that a final or annual report will be filed with the Division detailing final disposition of each individual specimen, along with a copy of any published papers resulting from the study of these plants.

4. Procedure for obtaining a Permit: Application materials should be submitted to the Chief of the Division of Natural Areas and Preserves. A permit will not be granted unless all submission requirements are met. A permit is valid for 1 year.

5. Permittee Requirements: A permit must be displayed upon request to law enforcement officers. Permit requirements must be met or the permit will not be renewed. 
6. Fees: None

E. ADMINISTERING AGENCY: Division of Natural Areas and Preserves

Department of Natural Resources

Fountain Square

Columbus, OH 43224

(614) $466-7803$ 


\section{$6 \cdot 1.3$ WILDLIFE}

INTRODUCTION: The Ohio Preservation of Endangered Species Law was enacted in part to implement parts of the U.S. Endangered Species Conservation Act of 1969. The Ohio Department of Natural Resources, Division of Wildlife administers a regulatory program involving a scientific collecting permit process.

A. NAME OF PERMIT: Scientific Collecting Permit

B. AUTHORIZING STATUTE: Preservation of Endangered Species, Section 1531.25, Ohio Revised Code

C. TITLE OF REGULATION: Scientific Collecting Permit Regulations, Section 1501:31-25-01, Ohio Administrative Code

D. SUMMARY OF PERMIT PROCESS:

1. Applicability: The collection of specimens of wildiife which are protected by law for scientific or educational purposes.

2. General Requirements: Scientific collecting permits are issued for collecting species threatened with statewide extinction for zoological, educational, and scientific purposes, and for propagation in captivity to preserve the species.

3. Submission Requirements: An application is submitted to the Division of wildlife on a designated form which details 1) the program or project outline and objective; 2) dates when the permit will be needed; 3) locations of collecting; 4) species with number to be collected and number to be retained; 5) method of collection, including any equipment or gear; and 6) 2 letters of reference from teachers or scientists supporting the applicant's qualifications.

4. Procedure for obtaining a Permit: When it appears that the application is made in good faith, the chief of the Division will issue a permit.

5. Permittee Requirements: The permit must be carried by applicants. Permit holders must keep daily records of all specimens collected and of the disposition of those specimens. In addition, an annual report must be filed with the Division. 
6. Fees: Annual permit fee: $\$ 2$.

E. ADMINISTERING AGENCY: Division of Wildlife

Department of Natural Resources

Fountain Square, Building C

Columbus, $\mathrm{OH} 43224$

(614) 466-5402 
INTRODUCTION: The Ohio Historical Society was chartered by the State of Ohio as a non-profit organization to promote knowledge of history and archaeology and it may perform public functions as prescribed by law. These functions include: 1) maintenance of a State Registry of Archaeological Landmarks and a State Registry of Historic Landmarks; 2) an Archaeological Preserve Program whereby the Ohio Historical Society may accept Articles of Dedication which are regarded as a conveyance of an interest in real property for the purpose of preserving archaeological resources; 3) all state departments, agencies, units, and political subdivisions are directed to cooperate with the Ohio Historical in the preservation of archaeological and historic sites and in the recovery of data from them; and 4) a permit requirement for archaeological work on public or protected lands. The Director of the Ohio Historical society is authorized to establish rules for archaeological preserves and landmarks.

Procedural guidelines, forms, and criteria for eligibility have been developed but have yet to be implemented.

A. AUTHORIZING STATUTE: Sections 149.51 through 149.55 , Dhio Revised Code

B. ADMINISTERING AGENCY: Division of Historic Preservation

Ohio Historical Society

Interstate 71 at 17 th Avenue

Columbus, 0.443211

(614) $466-1500$ 


\section{WETLANDS}

INTRODUCTION: At present the State of Ohio has no regulatory authority or permit procedures with respect to the protection of wetlands areas. However, applications for U.S. Army Corps of Engineers' Section 404 permits are reviewed by the ohio Department of Natural Resources and the Ohio Environmental Protection Agency for consistency with state water quality standards and requirements. During the 30-day review and comment period established for section 404 permits, interested citizens may submit comments to these 2 state agencies or directly to the Corps. In addition, the Ohio Department of Natural Resources has identified wetlands areas along the coast of Lake Erie and a policy statement calls for the protection of these areas.

\section{ADMINISTERING AGENCY:}

Environmental Review Section

Department of Natural Resources

Fountain Square, Building E-2

Columbus, OH 43224

(614) $466-6557$ 
INTRODUCTION: Ohio's legislature has not authorized a coastal zone management program for the Lake Erie coastal region. There is no comprehensive program therefore, to regulate activities in the coastal zone. Existing regulatory programs dealing with such areas as removal of minerals, oil and gas wells, and flood plain management do apply to the Lake Erie region. Chapter 3.1.4. of this guide contains information concerning the removal of minerals from Lake Erie.

ADMINISTERING AGENCY: Division of water

Department of Natural Resources

Fountain Square

Columbus, OH 43224

(614) 466-2645 
SECTION 7.0

LOCAL REGULATORY POLICY 
INTRODUCTION: The Constitution of the state of Ohio specifies that those powers not specifically reserved therein for the state are the responsibility of the local political subdivisions. Article XVIII, Section 7 concerns home rule and states "any municipality may frame and adopt or amend a charter for its government and may, subject to the provisions of Section 3 which gives municipalities the powers of local self government, exercise thereunder all powers of local self government." Ohio has no state zoning or planning law. However, the Ohio Revised Code does contain enabling legislation for zoning, subdivision regulations, development controls, new community development, transportation, and environmental protection.

A. AUTHORIZING STATUTE: Constitution of the state of Ohio, Article XVIII: Municipal Corporations

8. ADMINISTERING AGENCY: Individual cities and towns within the State of Ohio

For more information contact:
Department of Economic and Community Development

State Office Tower

30 East Broad Street

Columbus, $\mathrm{OH} 43215$

(614) $466-6300$ 